\title{
PENGGUNAAN PENDEKATAN SAVI UNTUK MENINGKATKAN AKTIVITAS DAN HASIL BELAJAR APRESIASI MUSIK NUSANTARA PADA SISWA KELAS VIII-7 SMP NEGERI 6 TEBING TINGGI
}

\author{
Hermina \\ Surel : hhermina31@gmail.com
}

\begin{abstract}
ABSTRAK
Penelitian ini bertujuan untuk mengetahui Penggunaan pendekatan SAVI dalam meningkatkan aktifitas belajar apresiasi musik nusantara pada siswa kelas VIII-7 SMP Negeri 6 Tebing Tinggi. Penelitian ini merupakan penelitian deskriptif kualitatif. Pada siklus 1 aspek perhatian 29 anak skor tinggi, interaksi 29 anak skor tinggi, penugasan 29 anak skor tinggi dan kerjasama 28 anak skor tinggi. Pada siklus 2 aspek perhatian 34 anak skor tinggi, interaksi 34 anak skor tinggi, penugasan 34 anak skor tinggi dan kerjasama 33 anak skor tinggi. Sedangkan, nilai hasil belajar siswa pada pra siklus, siswa yang mengalami ketuntasan hanya $25 \%$. Pada siklus 1 ketuntasan siswa mengalami kenaikan sebesar 47\%. Pada siklus 2 pertemuan 1 ketuntasan siswa meningkat sebesar $65 \%$. Pada Siklus 2 pertemuan 2 ketuntasan siswa mengalami peningkatan sebesar $90 \%$.
\end{abstract}

Kata Kunci: Pendekatan SAVI, Meningkatkan Hasil Belajar

\section{PENDAHULUAN}

Pembelajaran adalah cara guru memberikan kesempatan kerja pada siswa untuk berpikir agar dapat mengenal dan memahami apa yang sedang dipelajari (Darsono Max, 2000: 24). Dalam proses pembelajaran, komponen utama adalah guru dan siswa. Menurut Sudaryo (1994: 31) komponen yang lain adalah materi, metode, evaluasi hasil belajar, media pembelajaran, administrasi pembelajaran, sarana dan prasarana pembelajaran. Kegiatan pembelajaran merupakan kegiatan utama dalam proses pendidikan di sekolah.Keberhasilan pendidikan banyak bergantung pada kualitas pelaksanaan proses pembelajaran. Semua pihak yang berkepentingan dengan dunia pendidikan tentu berharap agar setiap siswa dapat mencapai hasil belajar yang baik, sesuai dengan kemampuan masing-masing. Kenyataannya tidak semua siswa dapat mencapai hasil belajar sesuai yang diharapkan. Salah satu masalah yang mendasar dalam dunia pendidikan adalah bagaimana usaha untuk meningkatkan pembelajaran, sehingga memperoleh hasil yang efektif dan efisien. Pendidikan tidak lagi hanya dilihat dari dimensi rutinitas, melainkan harus diberi makna mendalam dan bernilai bagi perbaikan kinerja sebagai salah satu instrumen utama pengembangan sumber daya manusia dengan multi kemampuan kognitif, afektif dan psikomotorik. Oleh karena itu, penyelenggaraan pendidikan menghendaki perencanaan dan pelaksanaan yang matang agar hasil yang diharapkan tercapai dan terwujud secara maksimal. Kemajuan 
ilmu pengetahuan dan teknologi yang memasuki era globalisasi sekarang ini menuntut peningkatan mutu pendidikan. Usaha menuntut pendidikan sebagai titik tolak pembangunan pendidikan menghendaki perlunya penilaian terhadap semua komponen pendidikan dan komponen pembelajaran yang ada dan selanjutnya mengadakan langkahlangkah perbaikan dan penyempurnan. Mata pelajaran Seni Budaya diberikan di satuan pendidikan formal penyelenggaraan pendidikan kesetaraan karena keunikan, kebermaknaan dan kebermanfaatan terhadap kebutuhan perkembangan peserta didik, yang terletak pada pemberian pengalaman estetik dalam bentuk kegiatan berekspresi, berkreasi dan berapresiasi melalui pendekatan “ belajar dengan seni", "belajar melalui seni" dan "belajar tentang seni". Peran ini tidak dapat diberikan oleh mata pelajaran lain. SMP Negeri 6 Tebing Tinggi dipilih dan dijadikan tempat penelitian karena didasari dari observasi yang pernah dilaksanakan peneliti sebelumnya. Hasil pengamatan menunjukan pembelajaran Seni Budaya yang telah dilaksanakan lebih menekankan pada pemberian materi oleh guru kepada siswa dengan tingkat aktifitas siswa yang rendah.Mata pelajaran Seni Budaya (Seni musik) kelas VIII-7 SMP Negeri 6 Tebing Tinggi terdapat kompetensi dasar : mengidentifikasi jenis karya seni musik tradisional nusantara. Tujuan pembelajaran adalah : siswa dapat mengidentifikasi karya seni musik tradisional dalam sebuah pembelajaran Seni Budaya.

$$
\text { Pendekatan }
$$

sebelumnya pernah diterapkan dalam disiplin bidang ilmu lain yaitu ilmu alam atau sains, dikarenakan dalam ilmu sains tidak hanya mengajarkan secara materi tetapi diperlukan adanya percobaan-percobaan melalui berbagai media untuk menguatkan materi yang diajarkan. Peneliti mencoba menerapkan pendekatan SAVI kedalam pembelajaran Seni Budaya. Hal ini dikarenakan mata pelajaran Seni Budaya tidak hanya mempelajari tentang materi tetapi diperlukan adanya percobaanpercobaan dan pembelajaran melalui berbagai media untuk menguatkan materi yang diajarkan, khususnya dalam hal berapresiasi. Pendekatan SAVI digunakan sebab memiliki keunggulan antara lain : (1) Sesuai asas PAIKEM (Pembelajaran Aktif, Inovatif, Kreatif, Efektif, dan Menyenangkan). (2) Pembelajaran berpusat pada siswa sehingga siswa berkesempatan banyak berlatih. (3) Pembelajaran yang memanfaatkan indra sebanyak mungkin, dan membuat seluruh tubuh/pikiran terlibat dalam proses pembelajaran. (4) Efektifitas dalam proses pembelajaran. Pendekatan SAVI selain mempunyai keunggulankeunggulan sebagaimana yang telah disebutkan, juga memiliki spesifikasi, yaitu : Membangkitkan kecerdasan terpadu siswa secara penuh melalui 
penggabungan gerak fisik dengan aktifitas intelektual.

Memunculkan suasana belajar yang lebih baik, menarik dan efektif. (3) Mampu membangkitkan kreatifitas dan meningkatkan kemampuan psikomotor siswa.

Memaksimalkan ketajaman konsentrasi siswa melalui pembelajaran secara visual, auditori dan intelektual. (2) Memunculkan suasana belajar yang lebih baik, menarik dan efektif. (3) Mampu membangkitkan kreatifitas dan meningkatkan kemampuan psikomotor siswa. (4) Memaksimalkan ketajaman konsentrasi siswa melalui pembelajaran secara visual, auditori dan intelektual. Dari uraian permasalahan di atas, peneliti tertarik untuk melakukan penelitian tentang pembelajaran apresiasi pada mata pelajaran Seni Budaya melalui pendekatan SAVI di SMP Negeri 6 Tebing Tinggi.

Berdasarkan pada permasalahan di atas maka hasil yang akan dicapai dalam penelitian ini adalah untuk mengetahui, mendeskripsikan dan menganalisis :

a. Penggunaan pendekatan SAVI dalam meningkatkan aktifitas belajar apresiasi musik nusantara pada siswa kelas VIII-7 SMP Negeri 6 Tebing Tinggi.

b. Penggunaan pendekatan SAVI dalam meningkatkan hasil belajar apresiasi musik nusantara pada siswa kelas VIII-7 SMP Negeri 6 Tebing Tinggi.

\section{METODE PENELITIAN}

Penelitian ini menggunakan Penelitian Tindakan Kelas (PTK). Penelitian yang dilakukan oleh guru di kelasnya sendiri dengan cara merencanakan, melaksanakan, dan merefleksikan tindakan secara kolaboratif dan partisipatif dengan tujuan memperbaiki kinerjanya sebagai guru, sehingga hasil belajar siswa dapat meningkat disebut PTK (Kusumah dan Dwitagama 2010: 9). Desain penelitian dalam penelitian ini menggunakan jenis penelitian tindakan kelas (PTK). Dalam pelaksanaan PTK, peneliti menggunakan metode kolaborasi (kerjasama) antara peneliti dan guru dalam melakukan pembelajaran apresiasi musik Nusantara. Penelitian ini terbagi dalam dua siklus yang diawali dengan tahap prasiklus. Prasiklus dilaksanakan dengan menyesuaikan pembelajaran yang biasa oleh guru, dengan tujuan untuk mengukur sejauh mana kemampuan siswa dalam berapresiasi sebelum menggunakan metode yang akan diterapkan peneliti. Siklus I dilaksanakan dengan tujuan untuk mengukur sejauh mana kemampuan siswa dalam berapresiasi dengan menggunakan metode yang diterapkan. Siklus II dilaksanakan dengan tujuan untuk melihat peningkatan atau perkembangan siswa dalam mengapresiasi musik Nusantara.

Penelitian ini dilaksanakan di SMP Negeri 6 Tebing Tinggi pada siswa kelas VIII-7 semester 2 tahun pelajaran 2016/2017 yang 
dilaksanakan dalam 2 siklus dengan perincian: siklus I dilaksanakan 2 kali pertemuan yaitu tanggal 13 dan 20 April 2017. Siklus II dilaksanakan 2 kali pertemuan, yaitu tanggal 27 April dan 4 bulan Mei 2017. Penentuan waktu dilaksnakan tindakan kelas disesuaikan dengan jadwal tugas mengajar dan pembahasan kompetensi dasar: mengidentifikasi jenis karya seni musik tradisional nusantara.

Obyek penelitian adalah siswa kelas VIII-7 SMP Negeri 6 Tebing Tinggi, semester genap tahun pelajaran 2016/2017 dengan jumlah 40 siswa yang terdiri dari 18 laki laki dan 22 perempuan. Kelas VIII-7 dijadikan obyek penelitian dengan pertimbangan bahwa hasil belajar kelas tersebut setelah dilakukan pembelajaran oleh guru dengan materi kompetensi mengidentifikasi jenis karya seni musik tradisional nusantara dengan $\mathrm{KKM}=75$ ketuntasan secara klasikal pada kondisi awal baru mencapai 25\% dibandingkan dengan kelas lain.

\section{HASIL PENELITIAN DAN PEMBAHASAN}

Peneliti telah mengadakan pengamatan selama satu bulan ( awal April - awal Mei 2017) dengan cara tidak langsung maupun langsung. Pengamatan dilakukan pada awal penelitian untuk memperoleh data mengenai gambaran umum SMP Negeri 6 Tebing Tinggi. Sedangkan pengamatan secara langsung dilakukan pada jam pelajaran Seni
Budaya untuk memperoleh data mengenai proses pembelajaran Seni Budaya, khususnya pada pokok bahasan mengapresiasi karya seni musik melalui Penelitian Tindakan Kelas yang dilakukan oleh peneliti.

\section{Pembahasan}

Siswa kelas VIII-7 SMP Negeri 6 Tebing Tinggi berjumlah 40 anak yang terdiri atas 18 laki-laki dan 22 perempuan. Dari 40 siswa yang mengikuti ulangan harian 40 siswa. Soal ulangan harian sebanyak 15 butir dengan waktu 30 menit dan KKM 75. Hasil ulangan harian sangat rendah dimana nilai rataratanya hanya mencapai 71 dengan tingkat ketuntasan sebesar $25 \%$. Faktor penyebab rendahnya prestasi belajar Seni Budaya apresiasi musik nusantara siswa kelas VIII-7 tersebut siswa belum optimal dalam mengikuti proses pembelajaran. Upaya penanaman konsep yang dilakukan guru belum tepat. Proses pembelajaran masih berlangsung searah, artinya guru yang aktif sedangkan siswa pasif. Hasil belajar pada prasiklus diperoleh dari tes yang dilakukan peneliti yang berkolaborasi dengan guru mata pelajaran seni budaya.Kondisi awal prestasi belajar siswa sangat rendah dilihat dari nilai tertinggi hanya mencapai 78 , nilai tengah 71 dan nilai terendah 63. Rata- rata nilai kelas sebesar 71,3 dan ketuntasan hanya mencapai $25 \%$ dari 40 anak.

Tindakan yang diberikan kepada siswa dengan menerapkan pendekatan SAVI terlaksana dalam 
program pembelajaran pada siklus I merupakan tahap penanaman dan pemahaman konsep yang terdiri atas menanamkan dan memahamkan konsep. Pelaksanaan pembelajaran dilakukan dengan menggunakan pendekatan SAVI antara lain: Visual dilakukan dengan cara menunjukan tayangan video mengenai materi musik nusantara, kemudian Auditori dilakukan dengan cara guru memberikan ceramah atau informasi serta melakukan tanya jawab terhadap siswa. Selanjutnya, peneliti dan guru seni budaya dalam penelitian ini memanfaatkan media pembelajaran alat musik angklung sebagai media pembelajaran apresiasi musik nusantara, Somatis dilakukan dengan cara siswa diajak untuk memainkan angklung secara individu dan berurutan. Untuk tahap yang terakhir, aspek Intelektual dilakukan peneliti dan guru dengan berkolaborasi memberikan tes kepada siswa untuk mengetahui sejauh apa siswa dapat menerima materi yang diajarkan. Penerapan berbagai metode pembelajaran tersebut dapat menarik minat siswa.Pada siklus I prestasi belajar siswa mengalami peningkatan. Hal ini dapat dilihat dari hasil belajar yang didapat pada siklus I dengan nilai tertinggi mencapai 80 , nilai tengah 76 dan nilai terendah 68 . Rata- rata nilai kelas sebesar 74,9 dan ketuntasan mencapai $47 \%$ dari 40 anak. Kolaborasi dengan guru mata pelajaran seni budaya melakukan pengamatan selama berlangsungnya

program

pembelajaran.

Berdasarkan hasil refleksi

siklus I, penulis menyusun perencanaan tindakan siklus II pertemuan 1 diawali menyusun RPPperbaikan. Tindakan dilaksanakan dalam bentuk program pembelajaran. Program pembelajaran Siklus II pertemuan 1 dengan penerapan pendekatan SAVI merupakan tahap melakukan percobaan. Penerapan pendekatan SAVI diharapkan menumbuhkan semangat siswa dalam belajar. Aktivitas siswa belajar Seni Budaya menjadi lebih tinggi karena pembelajaran yang menyenangkan. Penerapan pendekatan SAVI dalam proses pembelajaran pada siklus II pertemuan 1 antara lain: Visual dilakukan dengan cara menunjukan tayangan video mengenai materi musik nusantara, kemudian Auditori dilakukan dengan cara guru memberikan ceramah atau informasi serta melakukan tanya jawab terhadap siswa. Selanjutnya, peneliti dan guru seni budaya dalam penelitian ini kembali memanfaatkan media pembelajaran alat musik angklungsebagai media pembelajaran apresiasi musik nusantara, Somatis dilakukan dengan cara siswa diajak untuk memainkan angklung secara berkelompok dan bergantian. Untuk tahap yang terakhir, aspek Intelektual dilakukan peneliti dan guru dengan berkolaborasi memberikan tes kepada siswa untuk mengetahui sejauh apa siswa dapat menerima materi yang diajarkan.Pada siklus II 
pertemuan 1 prestasi belajar siswa mengalami peningkatan. Hal ini dapat dilihat dari hasil belajar yang didapat pada siklus II pertemuan 1 dengan nilai tertinggi mencapai 82 , nilai tengah 77 dan nilai terendah 70 . Rata-rata nilai kelas sebesar 77 dan ketuntasan mencapai $65 \%$ dari 40 anak. Kolaborasi dengan guru mata pelajaran seni budaya melakukan pengamatan selama berlangsungnya program pembelajaran.

Berdasarkan hasil refleksi siklus II pertemuan 1, penulis menyusun perencanaan tindakan Siklus II pertemuan 2 diawali menyusun RPP perbaikan. Tindakan dilaksanakan dalam bentuk program pembelajaran. Program pembelajaran Siklus II pertemuan 2 dengan penerapan pendekatan SAVI merupakan tahap melakukan percobaan. Penerapan pendekatan SAVI diharapkan menumbuhkan semangat siswa dalam belajar. Aktivitas siswa belajar Seni Budaya menjadi lebih tinggi karena pembelajaran yang menyenangkan. Penerapan pendekatan SAVI dalam siklus II pertemuan 2 antara lain: Visual dilakukan dengan cara menunjukan tayangan video mengenai materi musik nusantara, kemudian Auditori dilakukan dengan cara guru memberikan ceramah atau informasi yang lebih serta melakukan tanya jawab terhadap siswa. Selanjutnya, peneliti dan guru seni budaya dalam penelitian ini kembali memanfaatkan media pembelajaran alat musik angklung sebagai media pembelajaran apresiasi musik nusantara, Somatis dilakukan dengan cara siswa diajak untuk memainkan angklung secara berkelompok dan bergantian. Untuk tahap yang terakhir, aspek Intelektual dilakukan peneliti dan guru dengan berkolaborasi memberikan tes kepada siswa untuk mengetahui sejauh apa siswa dapat menerima materi yang diajarkan. Pada siklus II pertemuan 2 prestasi belajar siswa mengalami peningkatan. Hal ini dapat dilihat dari hasil belajar yang didapat pada siklus II pertemuan 2 dengan nilai tertinggi mencapai 86 , nilai tengah 81 , nilai terendah 74 dan rata-rata nilai kelas sebesar 79,7. Kondisi Siklus II pertemuan 2 meningkat dilihat dari rata-rata kelas dan ketuntasan 90\%. Kolaborasi dengan guru mata pelajaran Seni Budaya melakukan pengamatan selama berlangsungnya program pembelajaran.

\section{SIMPULAN}

Berdasarkan hasil penelitian dapat disimpulkan sebagai berikut: Penerapan metode SAVI dalam pembelajaran apresiasi musik nusantara dapat meningkatkan aktifitas siswa dari perhatian, interaksi, tugas dan kerjasama dalam pembelajaran apresiasi musik nusantara dan dapat meningkatkan nilai tambah siswa. Hal tersebut dapat dilihat dari hasil aktifitas yang dicapai siswa. Hasil aktivitas siswa yang berjumlah 40 anak pada prasiklus antara lain pada aspek perhatian 13 anak pada kriteria tinggi, 15 anak pada kriteria sedang, 
12 anak pada kriteria rendah. Pada aspek interaksi 14 anak pada kriteria tinggi, 16 anak pada kriteria sedang, 10 anak pada kriteria rendah. pada aspek tugas 13 anak pada kriteria tinggi, 16 anak pada kriteria sedang, 11 anak pada kriteria rendah. Pada aspek kerjasama 12 anak pada kriteria tinggi, 18 anak pada kriteria sedang, 10 anak pada kriteria rendah. Setelah diupayakan perbaikan pada siklus I, hasil aktivitas anak meningkat cukup pesat. Hal ini dapat dilihat dari aspek perhatian 22 anak pada kriteria tinggi, 9 anak pada kriteria sedang, 9 anak pada kriteria rendah. Pada aspek interaksi 21 anak pada kriteria tinggi, 11 anak pada kriteria sedang, 8 anak pada kriteria rendah. Pada aspek tugas 22 anak pada kriteria tinggi, 10 anak pada kriteriasedang, 8 anak pada kriteria rendah. Pada aspek kerjasama 21 anak pada kriteria tinggi, 11 anak pada kriteria sedang, 8 anak pada kriteria rendah rendah. Dalam siklus II pertemuan 1 terjadi peningkatan aktivitas siswa. Hal ini dapat dilihat dari aspek perhatian 29 anak pada kriteria tinggi, 6 anak pada kriteria sedang, 5 anak pada kriteria rendah. Pada aspek interaksi 29 anak pada kriteria tinggi, 7 anak pada kriteria sedang, 4 anak pada kriteria rendah. pada aspek tugas 29 anak pada kriteria tinggi, 6 anak pada kriteria sedang, 5 anak pada kriteria rendah. Pada aspek kerjasama 28 anak pada kriteria tinggi, 8 anak pada kriteria sedang, 4 anak pada kriteria rendah. Dalam siklus II pertemuan 2 terjadi peningkatan yang lebih baik. Hal ini dapat dilihat dari aspek perhatian 34 anak pada kriteria tinggi, 4 anak pada kriteria sedang, 2 anak pada kriteria rendah. Pada aspek interaksi 34 anak pada kriteria tinggi, 5 anak pada kriteria sedang, 1 anak pada kriteria rendah. pada aspek tugas 34 anak pada kriteria tinggi, 3 anak pada kriteria sedang, 3 anak pada kriteria rendah. Pada aspek kerjasama 33 anak pada kriteria tinggi, 5 anak pada kriteria sedang, 2 anak pada kriteria rendah.

$\begin{array}{llr}\quad \text { Dapat } & \text { disimpulkan } & \text { juga } \\ \text { pendekatan } & \text { SAVI } & \text { dalam } \\ \text { pembelajaran } & \text { apresiasi } & \text { musik } \\ \text { nusantara dapat } & \text { meningkatkan hasil }\end{array}$
belajar siswa dalam mengidentifikasi jenis karya musik nusantara. Hasil belajar siswa dari 40 anak pada pra siklus hanya mencapai $25 \%$ yang berarti hanya 10 siswa yang memperoleh ketuntasan berdasarkan standar KKM. Dari hasil belajar yang didapatkan pada pra siklus, peneliti melakukanupaya perbaikan pada siklus I dan hasil belajar siswa mengalami peningkatan dengan ketuntasan mencapai $47 \%$ yang berarti 18 siswa memperoleh ketuntasan. Dari hasil yang didapatkan pada siklus I, kemudian peneliti melakukan upaya perbaikan kembali pada siklus II pertemuan 1 dan hasil belajar siswa mengalami peningkatan dengan ketuntasan sebesar $65 \%$ yang berarti 28 siswa memperoleh nilai ketuntasan. Dari hasil yang didapatkan pada siklus II pertemuan 1, peneliti kembali melakukan perbaikan pada siklus II pertemuan 2 dan hasil belajar siswa 
mengalami peningkatan yang jauh lebih baik yaitu mencapai $90 \%$ yang berarti 36 siswa memperoleh nilai ketuntasan. Dari hasil Aktivitas dan hasil belajar siswa yang diperoleh siswa di atas dapat disimpulkan bahwa pendekatan SAVI dalam pembelajaran apresiasi musik nusantara dapat meningkatkan aktifitas dan hasil belajar siswa.

\section{DAFTAR PUSTAKA}

Arikunto, Suharsimi. 2006. Prosedur Penelitian

Suatu Pendekatan Praktik. Jakarta: PT Rineka Cipta.

Asmani, Jamal Ma'mur. 2011. Tuntunan Lengkap Metodologi Praktis Penelitian Pendidikan. Jogjakarta: DIVA Press.

DePorter, Bobbi. 2005. Quantum Teaching: Mempraktikkan Quantum Learning di Ruang Kelas. Bandung: Kaifa.

Jazuli, M. 2008. Diktat Teori Kebudayaan. Semarang: Jurusan Sendratasik FBS UNNES.

Kusumah Wijaya dan Dedi Dwitagama. 2010. Mengenal Tindakan Kelas. Jakarta: PT. Indeks.

Meier, Dave. 2005. The Accelerated

Learning Handbook. Bandung:

PT Mizan Pustaka.

MGMP Seni Budaya SMP. 2009. Estetika, Seni Budaya untuk SMP/MTs Kelas VII. Surakarta: CV. Surya Badra.

Nugroho, Van Afian. 2010. Penelitian Pemanfaatan Siaran Musik di Televisi Sebagai
Media Alternatif Pembelajaran Apresiasi Musik. Semarang: Univesritas Negeri Semarang.

Purnomo, Wahyu dkk. 2010. Terampil Bermusik. Surakarta: CV. Putra Nugraha.

Setiawati, Rahmida dkk. 2007. Seni Budaya 1. Bogor: Yudhistira.

Sumiati, Asra. 2009. Metode Pembelajaran. Bandung: CV. Wacana Prima.

Trianto. 2011. Mendesain Model Pembelajaran InovatifProgresif. Jakarta: Kencana Prenada Media Group. 